\title{
Military Corruption in China: The role of guanxi in the buying and selling of military positions*
}

\author{
Peng Wang*
}

\begin{abstract}
How does guanxi facilitate corrupt transactions? Utilizing fieldwork data and published materials, this paper investigates how guanxi practices distort the formal military promotion system and facilitate the buying and selling of military positions in the People's Liberation Army (PLA). It identifies three key functions of guanxi in facilitating corrupt transactions: communication, exchange and neutralization. Guanxi enables effective and safe communication among corrupt military officers, holds transaction partners to their word, and neutralizes their guilt about committing corrupt acts.
\end{abstract}

Keywords: China, military corruption, guanxi, promotion, the PLA

Since President Xi Jinping widened his anti-corruption drive within the PLA in 2014, dozens of generals have been placed under investigation or convicted of corruption, including two vice chairmen of the Central Military Commission (CMC), Xu Caihou and Guo Boxiong. ${ }^{1}$ The vast majority of generals caught in the anti-corruption campaign are from the General Political Department (GPD), the General Logistics Department (GLD) and military regions' logistics departments, which control the selection of army officers and the enormous budgets that fund infrastructure and supplies. $^{2}$ The downfall of these generals, especially $\mathrm{Xu}$, who was in charge of personnel matters for 13 years, revealed the problem of buying and selling military positions. ${ }^{3}$ A retired PLA major-general, Yang Chunchang, points out that the strength of a candidate's guanxi and his or her willingness to make bribe payments were essential criteria for recruitment to and allocation of military positions during Xu's tenure. ${ }^{4}$ This prompted the author to explore the following questions: (1) what

\footnotetext{
${ }^{*}$ I greatly appreciate the helpful comments and suggestions from Vivian Jing Zhan, Karen Joe Laidler, Alistair Fraser, Cheris Chan, Maggy Lee, Li Li, Xia Yan, Hilary Wright, Jingyi Wang, the anonymous referees and editors at The China Quarterly, and staff seminar participants at the Department of Sociology, University of Hong Kong. I also thank Mr Zhao and Ms Wang for their help during the fieldwork. All errors remain my own.

** Department of Sociology, The University of Hong Kong, Hong Kong, China. Email: pengwang@hku.hk.

${ }^{1}$ Scmp.com. 2015. "Aide of former Chinese generals Xu Caihou, Guo Boxiong now facing graft probe," 14 February, http://www.scmp.com/news/china/article/1712424/aide-former-pla-generals-xu-caihouguo-boxiong-put-under-graft-probe. Accessed 15 October 2015.

${ }^{2}$ The number of military officers exposed may be only the tip of the iceberg. The evidence so far disclosed by the Chinese government is, however, insufficient for the author to assess how common the buying and selling of military positions is. For discussion, please see: Mulvenon 2015, 3 .

${ }^{3}$ Chase, et al. 2015.

${ }^{4}$ Xinhuanet.com. 2015. "Shaojiang bao Xu Caihou maiguan neimu" (Retired generals point to the military's serious problem of selling military positions), 10 March, http://news.xinhuanet.com/legal/2015-03/10/c_127562610.htm. Accessed 15 October 2015.
} 
role does guanxi play in the buying and selling of military positions? (2) What is the relationship between bribe payments and guanxi in this process?

A PLA officer ${ }^{5}$ who sells military positions is able to help the buyer transfer to a better position at the same grade level (lateral transfer) or gain promotion to the next level up. ${ }^{6}$ Each PLA officer is assigned one of 15 grade levels (zhiwu dengji, 职务等 级) which determine the officer's status and authority in the PLA hierarchy. ${ }^{7}$ Although officers at the same grade level are equal in status, they occupy different positions (zhiwei, 职位) with different duties and powers. For example, a logistics officer in charge of fuel and supplies has more opportunity to obtain corrupt benefits than a specialized technical officer at the same grade level. In a given unit, the head of the cadre department has a higher chance of gaining promotion than the head of the publicity department even though they are always the same grade. ${ }^{8}$ These differences create incentives for PLA officers to use corrupt practices to transfer to a better position at the same grade level.

The PLA has also established its rank (junxian, 军衔) system. In contrast with the U.S. military that has " 10 officer grades and 10 equivalent ranks", the PLA "has 15 grades and 10 ranks". 9 The terms "grade" and "rank" are not synonymous in the PLA, and each rank is associated with one to four grade levels. ${ }^{10}$ That is to say, officers' ranks do not dictate their exact grades, authorities or responsibilities. As Allen explains, "rank is a key indicator of position within the hierarchy of foreign militaries", while "grade [that is based on an officer's position] is the key indicator of authority within the PLA". ${ }^{11}$ As a result, PLA officers care more about position and grade rather than rank. $^{12}$

The existing literature on Chinese military corruption pays special attention to how the military's resurgent commercialization in the 1980s and 1990s led to an explosion of corruption ${ }^{13}$ and smuggling ${ }^{14}$, but the buying and selling of military positions remains largely unexplored in the literature. Guanxi researchers have noted the corrosive effects of guanxi within China's weak institutional environment and the relationship between guanxi practices and corruption, ${ }^{15}$ but these researchers excluded the study of guanxi's role in military corruption because this topic lacks empirical

\footnotetext{
${ }^{5}$ Based on the nature of positions, PLA officers are classified as commanders, political officers, logisticians, armaments officers, specialized technical officers and academic staff.

${ }^{6}$ Skype interview with former military officer S, December 2015.

${ }^{7}$ Kaufman and Mackenzie 2009.

${ }^{8}$ Skype interview with former military officer T, December 2015.

${ }^{9}$ Allen and Shraberg 2011, 7.

${ }^{10}$ For example, a "regiment leader-grade officer" should hold the rank of colonel or lieutenant colonel, while a lieutenant colonel may hold "the grade level of regiment leader, or regiment deputy leader, or battalion leader". Please see: Kaufman and Mackenzie 2009, 75.

${ }^{11}$ Allen 2010, 6.

${ }^{12}$ Skype interview with former military officer $\mathrm{T}$.

${ }^{13}$ Chao 2013; Chase et al. 2015; Cheung 2001; Mulvenon 2003 and 2006.

${ }^{14}$ Shieh 2005.

${ }^{15}$ Bian 1997; Lovett et al. 1999; Xin and Pearce 1996.
} 
evidence. The aim of this paper is to contribute to the study of 'the corruptionfacilitating roles of guanxi ${ }^{16}$ by investigating military corruption in the People's Republic of China. Specifically, it examines the negative effect of guanxi practices on the formal promotion system in the military and identifies how guanxi facilitates the buying and selling of military positions.

\section{Concept and theory}

\section{Guanxi and guanxi practice}

Guanxi (关系) is frequently translated as a Chinese version of "social connections", "particularistic ties" or "personal networks", but these translations are not perfect because of "the complicated and rich meaning of the word" $"$. The meaning of guanxi varies according to context and, as Li argues, requires "the unspoken understanding of the contextual situation in which the conduct described in the conversation takes place". ${ }^{18}$ For example, when one says, "lao Zhang shi wode guanxi" (senior Zhang is my guanxi, 老张是我的关系), the speaker uses guanxi to refer to a person; when one says, “laoban you henduo guanxi” (my boss has a lot of guanxi, 老板有很多关系), guanxi refers to social resources. Guanxi also refers to an act when it is used in verbphrases, such as “zou guanxi (to go through guanxi, 走关系), la guanxi (to pull guanxi, 拉关系), gao guanxi (to play guanxi, 搞关系)". ${ }^{19}$ Guanxi scholars usually use the term "guanxi practice" to refer to these verb-phrases. Guanxi practice is defined by $\mathrm{Li}$ as

an amalgamated concept representing the conduct and the process of conduct of soliciting, receiving, offering or delivering a service by one party to another, which satisfies the following conditions: (1) the service involves the exercise of entrusted power by one party, resulting in favorable treatment to the other, which also means that at least one of the parties is endowed with entrusted power, most notably, from a public entity; (2) the service is delivered either as a reciprocation to a favor previously received from the other party or as an act to generate proper reciprocation from the other party in the specified or unspecified future. ${ }^{20}$

Guanxi and guanxi practice, as Keister points out, are "key to understanding all manner of social relations in China". ${ }^{21}$ The formation and maintenance of guanxi, as Qi argues, need to "follow implicit social norms which seem to be purely local in their sense if not meaning". ${ }^{22}$ Key norms of guanxi include the principles of reciprocity,

\footnotetext{
${ }^{16}$ The theory of 'the corruption-facilitating roles of guanxi' is generated by Zhan in his journal article 'Filling the gap of formal institutions'. For more discussion, please see: Zhan 2012.

${ }^{17}$ King 1991, 68.

${ }^{18} \mathrm{Li}$, Ling 2011b, 166.

${ }^{19}$ Ibid.

${ }^{20} \mathrm{Li}$, Ling 2011a, 4.

${ }^{21}$ Keister 2012; Chen, Chen and Huang 2013.

${ }^{22}$ Qi 2012, 309-10.
} 
mianzi (face, 面子), renqing (obligation, 人情) and ganqing (affection or sentiment, 感情). ${ }^{23}$ Chinese culture emphasizes the importance of maintaining social harmony, requiring Chinese people to fulfill the "reciprocal obligations expected of all the parties in a social relationship". ${ }^{24}$ Failing to meet reciprocal expectations and obligations leads to the loss of mianzi - a person's "social position or prestige" that enables him or her to gain access to resources or get things done. ${ }^{25}$ Renqing refers to the obligation to exchange symbolic and material resources within guanxi networks in order to build one's mianzi and cultivate ganqing with other guanxi members. ${ }^{26}$ Ganqing, as an affective component of guanxi and "an indicator of closeness of guanxi"," "functions more as a safeguard measure for the favour-grantor to guarantee the return of the favour" 28 .

\section{The importance of guanxi in corrupt transactions}

China scholars view guanxi as an informal institution, substituting for or complementing the formal legal system in transitional China. ${ }^{29}$ To be specific, private individuals and entrepreneurs tend to employ guanxi practices to protect property rights, safeguard transactions, obtain state-owned resources and resolve disputes in weak institutional environments characterized by a lack of market mechanisms and legal infrastructure. ${ }^{30}$ Moreover, guanxi networks, as Chang argues, are "used to bypass officially sanctioned, and onerous, bureaucratic procedures, solicit protection from more powerful actors, and acquire otherwise unavailable resources". 31

Guanxi networks not only function as substitutive informal institutions for "achieving what formal institutions are designed, but fail, to achieve",32, but also offer efficient governing mechanisms to solve problems encountered during corrupt transactions. Compared with legal market transactions that are facilitated by market mechanisms and protected by the formal legal system, the actors in corrupt exchanges have to cope with a high level of environmental and behavioral uncertainty. ${ }^{33}$ The major threat for corrupt transactions is the risk of punishment, compelling transaction partners to create an operating environment that is characterized by a high degree of secrecy and opacity. ${ }^{34}$ Such an operating environment, however, leads to limited participation and limited exchange of information, preventing transaction participants from efficiently gathering information, evaluating the quality of corrupt services, and assessing

\footnotetext{
${ }^{23}$ Fan 2002a; Zhan 2012.

${ }^{24} \mathrm{Wu}$ and Leung 2005, 448.

${ }^{25}$ Merrilees and Miller 1999, 268

${ }^{26}$ Luo 2000.

${ }^{27}$ Wang, Cheng Lu 2007, 82.

${ }^{28} \mathrm{Li}$, Ling 2011b, 170.

${ }^{29}$ Wang, Peng 2014.

${ }^{30}$ Chan 2009; Luo 2000; Peng 2003; Xin and Pearce 1996.

${ }^{31}$ Chang 2001.

${ }^{32}$ Wang, Peng 2014, 812.

${ }^{33}$ Della Porta and Vannucci 2005; see also Wang, Peng 2015.

${ }^{34}$ Lambsdorff 2002.
} 
potential partners' willingness to comply with corrupt contracts. ${ }^{35}$ A participant in a corrupt transaction suffers from a high risk of being cheated by the counterpart (i.e. the transaction is subject to high level of behavioral uncertainty). On the one hand, corrupt exchanges are usually non-simultaneous, creating incentive for opportunistic behavior; on the other hand, corrupt contracts cannot be enforced by formal institutions. ${ }^{36}$ In addition, corrupt transactions needs to tackle the moral cost of demanding bribes and performing bribery. ${ }^{37}$

Partners in corrupt transactions tend to employ guanxi practices to overcome these environmental and behavioral uncertainties. Recent years have witnessed a growing body of literature focusing on the ways in which guanxi facilitates corrupt transactions by coping with these uncertainties. ${ }^{38}$ The theory of "the corruptionfacilitating roles of guanxi" generated by Zhan suggests three functions of guanxi in enhancing opportunities and incentives for public officials to engage in corruption: communication, exchange and norms. ${ }^{39}$ First, the guanxi network functions as a transmitter of information, helping members to identify potential exchange partners. Second, trust and reputation within the guanxi network facilitates the exchange of corrupt benefits between public officials and businesspeople by guaranteeing the fulfilling of all the agreed obligations from both sides and minimizing the risk of being detected and punished. Third, the norm of gift-giving and the principle of reciprocity encourage government officials to meet the demand from guanxi networks regardless of laws and regulations; that is to say, normative elements of guanxi networks distort the legal norms designed by state authority.

Li's research concentrates on the significance of guanxi practices in acts of bribery in China by investigating how guanxi practices remove both legal and moral barriers, control exchange risks and reduce moral costs. ${ }^{40} \mathrm{As} \mathrm{Li}$ argues, exchanging favors with people who "are socially and/or sentimentally connected" is an effective strategy for reducing internal risks (e.g. non-performance of exchange partners) and external risks (e.g. the risk of exposure and the threat of legal punishment). ${ }^{41}$ This is because performing an opportunistic behavior with one exchange partner is equal to betray all members of the network, and collective responses from guanxi members to opportunistic behavior include the deprivation of membership benefits and even the exclusion of the opportunist from the guanxi network. ${ }^{42}$ The existing research into the function of guanxi networks in corrupt transactions offers a useful tool to help the author investigate the precise roles guanxi plays in the buying and selling of military positions.

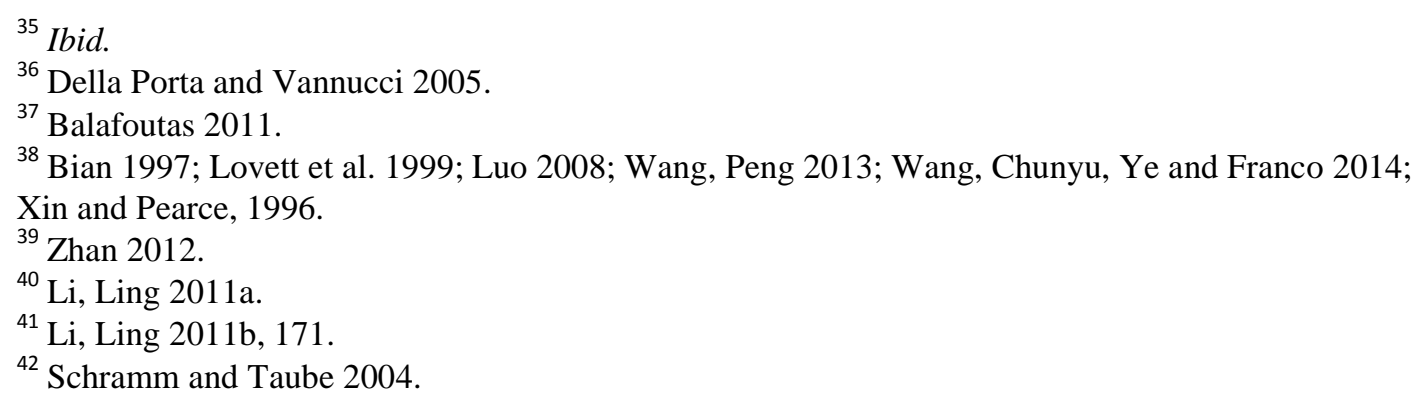




\section{Data and Methods}

Collecting reliable data was the most difficult part of this research. The project was initially designed to rely on analysis of existing Chinese military publications. Special attention was paid to PLA official newspapers, including Liberation Army Daily (jiefangjun bao, 解放军报), Air Force News (kongjun bao, 空军报), Rocket Force News (huojianbing bao, 火箭兵报), and People's Navy (renmin haijun, 人民海军). The author also made use of CNKI resources (China National Knowledge Infrastructure, 中国知网 $)^{43}$ and online searches using such keywords as "military corruption” (jundui fubai, 军队腐败), “buying and selling military positions” (jundui maiguan maiguan, 军队买官卖官), “anti-corruption in the PLA” (jiefangjun fanfu, 解 放军反腐) and “corruption related to appointment and promotion” (xuanren yongren fubai, 选人用人腐败). The published data, however, provided very limited information for the study of military corruption, especially the buying of promotion and the selling of position in the PLA. This encouraged the author to collect empirical data in China.

Doing fieldwork in China about military corruption is extremely difficult because it is one of the most politically sensitive topics. International scholars, including those from Hong Kong, are perceived as 'enemies' by PLA officers and researchers. The investigator found it very hard to gain access to interviewees; they either declined invitations for interview altogether or merely offered information or viewpoints that were identical to news reports on state-owned media. The use of personal connections to collect data is perceived by scholars as the most effective strategy to obtain reliable information in mainland China. ${ }^{44}$ Unfortunately, this strategy is not always useful. The investigator employed his personal connections with PLA officers and relied on middlemen when such connections did not exist, but most of the PLA officers contacted still refused to be interviewed. The major concern for these officers was that their participation might impair their chances for promotion.

The problem was not resolved until a middleman suggested the investigator should interview soon-to-be-demobilized PLA officers and retired officers. The investigator managed to conduct 20 interviews with PLA officers, former army officials and a military researcher. The quality of interview data from former military officers and army officials who are close to retirement is high, because sharing their perceptions of military corruption does not result in any significant career risk. Information from active-duty PLA officers and the military researcher, although limited, is helpful to test the validity and reliability of the interview data from the retired and soon-to-bedemobilized officers. These interviews on the buying and selling of military positions generated around 87,000 words of transcript material.

\footnotetext{
${ }^{43} \mathrm{CNKI}$ is the largest and the most comprehensive distributor of academic digital resources in China developed by Tsinghua University. It offers full-text access to academic journals, newspapers, doctoral dissertations and conference papers.

${ }^{44}$ Heimer and Thøgersen 2006.
} 
The investigator only managed to conduct interviews with low- and mid-level PLA officers and failed to gain access to high-ranking army officials. In this case, fieldwork data is helpful to explain how low- and mid-level officers make use of guanxi practices when buying and selling military positions, but the data may be less helpful for identifying the causes for high-ranking PLA officers' involvement in the selling of military positions.

\section{Problems in the selection and appointment of military officers}

Fieldwork data suggests that formal rules for appointing PLA officers are distorted by guanxi practices and promotion opportunities are unjustly distributed within the military. This section therefore investigates problems in the decision-making process over promotions in the military and examines the logic of allocating promotion opportunities. As empirical data reveals, the selection and appointment of military officers follows the rule of guanxi (renren weiqin, 任人唯亲) rather than meritocratic principles (renren weixian, 任人唯贤).

\section{Concentration of power in the military promotion system}

The PLA has a set of formal rules for the appointment and promotion of personnel. Jiang Zemin, the core of the third generation of the Chinese Communist Party (CCP) leadership, tried to standardize the PLA promotion system. ${ }^{45}$ In December 2000, the $19^{\text {th }}$ meeting of the Standing Committee of the Ninth National People's Congress approved the amendment of the Regulations of the Chinese People's Liberation Army on the Military Services of Officers in Active Service. ${ }^{46}$ The new regulation aimed to create clear and uniform requirements for the appointment and removal of PLA officers. For example, Article 4 of the new regulation stresses the importance of political integrity, professional competence and measurable performance in the selection of officers. Article 10 states that operational, political, logistics and armaments officers should have received training in schools or academies prior to promotion.

The Party constitution stipulates that "all major issues should be decided upon by the party committees after discussion" in accordance to the principle of "collective leadership” (jiti lingdao, 集体领导), “democratic centralism” (minzhu jizhong, 民主 集中), “consultations before formal meetings” (huiqian yunniang, 会前酝酿) ${ }^{47}$, and “decisions through formal meetings" (huiyi jueding, 会议决定). ${ }^{48}$ This principle also applies to the selection and appointment of military officers, because the PLA is

\footnotetext{
${ }^{45} \mathrm{Li}$, Xiaobing 2012.

${ }^{46}$ For more information, please see: "Decision of the Standing Committee of the National People's Congress on Amending the Regulations of the Chinese People's Liberation Army on the Military Service of Officers in Active Service," 28 December 2000, http://en.pkulaw.cn/display.aspx?cgid=32107\&lib=law. Accessed 5 May 2015.

47 According to interviewees, "consultations before formal meetings" refers to "case-specific/ individual consultations” (gebie yunniang, 个别酝酿).

${ }^{48}$ Lin 2013, 39; see also Zeng 2015; Zuo 2015.
} 
controlled by the $\mathrm{CCP} .{ }^{49}$ However, the Party constitution fails to detail operational procedure for this decision-making principle, resulting in the ambiguous and flexible application of this principle and creating opportunities for superiors to abuse it for private profit. ${ }^{50}$ This is especially true for the military. On the one hand, the PLA emphasizes the importance of speed and efficiency in decision-making in order to improve conflict and crisis management. ${ }^{51}$ On the other hand, the decision-making process within the PLA is not subject to external monitoring by the media and civic groups. ${ }^{52}$ The need for efficient decision-making and the lack of external monitoring result in an opaque process for appointing military officers and the concentration of power over personnel selections in the PLA.

In practice, decision-making power is concentrated in the hands of two officers - the political officer and the commander - in every unit at the company level and above. This “dual-leadership system” (shuang zhuguan zhi, 双主官制) is designed to set up the mechanism of mutual supervision, but in reality the political officer and the commander tend to collaborate with each other to promote their common interests. ${ }^{53}$ A retired military officer offers his understanding of the mutually-beneficial network between the political officer and the commander:

This does not mean that these two officers must agree with each other all the time. They can disagree with each other. But they have to compromise to reach consensus and make decision together...solidarity among members of a party branch (dangwei banzi, 党委班子), especially between the political officer and the commander, is an important component of performance assessment. Frequent conflicts between them would raise inevitable questions about these officers' ability to cooperate, decreasing their chances of promotion. ${ }^{54}$

The concentration of power steers the selection and promotion processes away from collective leadership. The appointment of officers relies only on the principle of "consultations before formal meetings". ${ }^{55}$ Before decision-making through formal meetings, every member understood leaders' intentions and knew who would ultimately gain promotion; in other words, weak collective leadership leads to unfair distribution of promotion opportunities. ${ }^{56}$ In order to balance different interest groups, the political officer and the commander need to know what guanxi resources candidates possess, understand which positions candidates occupy in different guanxi networks, and examine whether the promotion of an officer will bring them personal benefit. ${ }^{57}$ That is to say, the distribution of promotion opportunities is not only the

\footnotetext{
${ }^{49}$ Interview with military officer H, Beijing, April 2015.

${ }^{50}$ Lin 2013; Yu 2010.

${ }^{51}$ Scobell and Wortzel 2005.

${ }^{52}$ Saunders and Scobell 2015.

${ }^{53}$ Ibid.

${ }^{54}$ Skype interview with former military officer P, October 2015.

${ }^{55}$ Interview with former military officer C, Tianjin, April 2015.

${ }^{56}$ Interview with former military officer L, Tianjin, April 2015.

${ }^{57}$ Interview with military officer $\mathrm{H}$.
} 
process of exchanging power for money but also an important way of seeking future rewards from guanxi networks.

\section{Privileged groups and hometown ties}

The lack of monitoring of officers who control personnel appointment and removal enables these officers to maximize their personal interests by creating tailored standards for the selection of competent officers. ${ }^{58}$ The existence of a special group of officers-“three types of princes" (sanye, 三爷)—has significantly destroyed motivation in the PLA and distorts public trust in the military. These 'princes' are sons of senior officers (shaoye, 少爷), sons-in-law of senior officers (guye, 姑爷) and secretaries of senior officers (shiye, 师爷). Although family members are not allowed to hold positions directly under the leadership of each other, senior officers have an immense incentive to employ all their resources to assist their relatives' promotions. ${ }^{59}$ Officers at the level of corps leader and above are allowed to have full-time secretaries. This long-term leader-subordinate relationship provides opportunities for senior officers and secretaries to share their emotional reactions to work-related and private issues, resulting in the development of deep affection for each other. Secretaries therefore occupy important positions in senior officers' guanxi networks and have obvious advantages when seeking promotion opportunities. ${ }^{60}$ Making use of the influence of senior members, these princes can gain promotions even though their profiles do not meet all the essential criteria, for example university training and work experience. The common practice is that after these princes get promoted, they find opportunities to fulfill the requirements they should have met before promotion. ${ }^{61}$

The hometown tie is another essential factor for selecting military officers. Reflecting the Chinese saying "fixed barracks, floating soldiers" (tieda de yingpan, liushui de bing, 铁打的营盘, 流水的兵), officer turnover in the military is high. The first and fundamental task a newly appointed unit leader has to deal with is to quickly take control of his unit's overall situation. A widely accepted strategy is appointing subordinate officers whom the unit leader trusts to important positions. Strong ties between the newly appointed unit leader and his subordinates sometimes do not exist at the beginning, requiring the unit leader to develop and nurture guanxi within the

\footnotetext{
${ }^{58}$ The PLA established the cadre department (ganbu $b u$, 干部部) in every unit at regimental level and above. Its purpose is to take charge of promotions and reassignments for military officers. But the cadre department tends to design promotion criteria based on the instruction of unit leaders - the political officer and the commander-due to the lack of independence. The head of the cadre department is commonly appointed by the unit party committee headed by unit leaders and the daily operation of this department is supervised by the same committee.

${ }^{59}$ China's one child policy has been strictly enforced in the PLA, which means that each military family only has one child. Familial obligations encourage senior officers to favor their children by ignoring laws and regulations.

${ }^{60}$ Interview with former military officer K, Tianjin, April 2015.

${ }^{61}$ Interview with military officer F, Beijing, April 2015.
} 
unit. Making use of guanxi bases ${ }^{62}$ helps the unit leader to establish strong relationships with subordinates within a short period. The unit leader will review officers' personnel files to identify officers from prominent military families or officers who come from the same hometown or graduated from the same university as the unit leader. ${ }^{63}$

The existence of guanxi bases enables two persons to build strong ties easily and quickly. ${ }^{64}$ Take the hometown tie (laoxiang guanxi, 老乡关系) for example; PLA officers tend to group together according to locality of origin. Officers who have hometown ties can quickly develop deep affection among each other due to the existence of a common language (gongtong yuyan, 共同语言), and speaking dialect shortens their psychological distance. ${ }^{65}$ The importance of guanxi, especially hometown ties, in the selection and promotion of officers encourages many lowerlevel officers to change their localities of origin in their personnel files and learn new dialects in order to secure promotion. ${ }^{66}$

\section{Costs of hard work and integrity}

Hard work is not the key for PLA officers to achieve career advancement. A widely accepted hidden principle in the PLA is that "conducting a dirty/bad thing together with your superior is better than doing ten good things for him/her" (gei lingdao ban shijian haoshi, buru yu lingdao ban yijian huaishi, 给领导办十件好事, 不如与领导 办一件坏事). ${ }^{67}$ To be specific, taking up additional workload and responsibility for the unit or senior members is not an effective strategy for promotion, because it does not add credit for hard work but increases the possibility of making mistakes. As a soon-to-be-demobilized PLA officer notes:

Mistakes are inevitable...doing more work than others means you have more chance of making a mistake, or unintentionally offending your superior(s). ${ }^{68}$

However, jointly committing corrupt activities ("dirty things") is one of the most effective ways for lower-level officers to win trust and affection from their leaders. 'Dirty things' refers to all types of corrupt activities, including reselling scarce resources monopolized by the military on the open market, embezzling military assets (money or property), creating false accounts, and assisting promotions by violating

\footnotetext{
${ }^{62}$ Guanxi bases, as Chen, Chen and Huang argue, "usually refer to pre-existing particularistic ties between two interacting parties". Tsang suggests that guanxi bases can be divided into blood bases and social bases. The existence of guanxi bases does not automatically produce active guanxi. The establishment of active guanxi needs triggers: finishing a task (shiqing, 事情) through the cooperation of two partners, a process through which xinren, ganqing and renqing are produced. For more discussion, please see: Chen, Chen and Huang 2013, 171; Fan 2002a; Tsang 1998.

${ }^{63}$ Interview with military researcher E, Beijing, April 2015.

${ }^{64}$ Fan $2002 b$.

${ }^{65}$ Interview with former military officer N, Beijing, April 2015.

${ }^{66}$ Interview with military researcher E.

${ }^{67}$ Interview with military officer $\mathrm{H}$; interview with former military officer $\mathrm{K}$.

${ }^{68}$ Interview with military officer $\mathrm{H}$.
} 
regulations. ${ }^{69}$ Collaboration in committing an immoral or illegal act is extremely helpful for lower-level officers to become key members of senior officers' guanxi networks.

It is important to note that not all military officers seek career advancement through corruption. In fact, there are many upright officers in the PLA, but they are more likely to be isolated by power-holders. ${ }^{70} \mathrm{~A}$ former military officer shared his experience of offending a senior officer due to his adherence to the principle of fairness:

A division deputy leader asked me to provide assistance for the promotion of his laoxiang (a junior officer who was from the same hometown as him). I was reluctant to offer assistance because his laoxiang, according to my perception, was unqualified for promotion. His promotion would be unfair to other competent candidates. I gave the leader the reasons why I was not able to help, but my refusal angered him. He threatened to remove me from my position, in the end I compromised. The outcome was that his laoxiang gained promotion as planned but I was given no opportunity for further promotion. ${ }^{71}$

The experience of this interviewee is described as "change the person if he does not change his mind" (buhuan sixiang jiu huanren, 不换思想就换人). Every PLA officer is required to unconditionally obey (juedui fucong, 绝对服从) his or her superior's orders and instructions, but there is a lack of guidance concerning what personnel should do if these orders contradict laws and regulations. ${ }^{72}$ There are two kinds of path from which a military officer may stray: the path laid down by his or her superiors, and the path designed by the full set of laws and regulations of the PLA and the CCP. A military officer has to make a choice when two paths do not coincide: selecting the first results in illegitimacy and choosing the second leads to insubordination. The rational choice made by the vast majority of officers is to unconditionally obey orders regardless of moral or legal doubts. ${ }^{73}$

To sum up, the concentration of power in the hands of superiors and the lack of external monitoring encourage superiors to maximize personal interests by following guanxi rules in the distribution of promotion opportunities. Military officers who belong to privileged groups (e.g. princes) or have hometown ties with superiors are more likely to gain promotion. The military norm of unquestioning obedience makes officers believe that unconditionally obeying superiors' unethical requests is both natural and moral, while officers who perform their duties strictly according to laws and regulations are more likely to offend their superiors and thus lose career advancement opportunities.

\footnotetext{
${ }^{69}$ Interview with former military officer $\mathrm{K}$.

${ }^{70}$ Interview with military officer $\mathrm{H}$.

${ }^{71}$ Interview with former military officer L.

${ }^{72}$ Kaufman and Mackenzie 2009.

${ }^{73}$ Skype interview with former military officer A, March 2015.
} 


\section{Functions of guanxi in the buying and selling of military positions}

Fieldwork data suggests that being a member of superiors' guanxi networks is costeffective: it enhances the chances of gaining promotion and decreases the risk of being punished. The attractive returns generated by guanxi networks encourage PLA officers to employ this informal mechanism to get things done. The following discussion therefore investigates the function of guanxi in the buying and selling of military positions: communication, exchange and neutralization.

\section{Communication}

Government officials and businesspeople involved in corrupt transactions need to find a secret and safe communication channel for information exchange, because information relating to bribery and corruption cannot be disclosed to the public. ${ }^{74}$ In order to avoid being caught by law enforcement agencies, buyers and sellers of corrupt benefits tend to rely on guanxi networks to gain access to secret and reliable information. ${ }^{75}$ The communication channel provided by guanxi networks is characterized by a high level of secrecy and lack of transparency as information is only available to insiders (i.e. guanxi members). ${ }^{76}$

While businesspeople rely on guanxi networks to identify government officials who are able to sell corrupt benefits, PLA officers do not have such concerns, for three reasons: (1) the military is a closed system and information about the sale of promotions in the PLA (e.g. 'price tags' for different positions ${ }^{77}$ ) is an open secret; (2) there is no need to identify a seller through guanxi networks, because the power to allocate appointments is concentrated in the hands of superiors; and (3) there is no need to look for buyers through guanxi networks, because under the "up or out" system, all officers, especially lower-ranking officers, have an incentive to buy promotions.

Although it is clear who the buyers and sellers are in the market of selling military positions, the importance of guanxi networks in identifying preferred transaction partners cannot be neglected. Faced with different buyers, the office seller tends to employ guanxi networks to collect reliable information about these potential buyers. This strategy enables the seller to assess the credibility and trustworthiness of each

\footnotetext{
${ }^{74}$ Zhan 2012.

${ }^{75}$ Ibid.

${ }^{76}$ Wang, Peng 2014.

${ }^{77}$ Reuters. 2014. "Disgraced China military officer sold 'hundreds' of posts: sources," 1 April, http://www.reuters.com/article/2014/04/01/us-china-military-idUSBREA300GH20140401. Accessed 8 May 2015

${ }^{78}$ Officer retirement ages have been established for operational, political and logistics officers in combat troops based on their grade levels; for example, age 30 for platoon leader, 35 for company leader, and 40 for battalion leader. PLA officers either get promoted or leave the military when they reach mandatory retirement ages. For details, please see: Allen and Corbett 2004; Kaufman and Mackenzie 2009.
} 
buyer. ${ }^{79}$ Similarly, before starting a transaction, the buyer tends to rely on guanxi networks to collect private and trustworthy information about the seller, such as reputation. Superiors who always meet their promises (e.g. assisting promotions) are defined as high-quality sellers. The reputation of those superiors who take bribes but do not deliver what they promised will be destroyed, because information about dishonest behavior can be quickly transmitted through guanxi networks. ${ }^{80}$ In addition, office buyers who do not possess direct connections with sellers have to employ guanxi networks to identify middlemen who can facilitate corrupt transactions. ${ }^{81}$

\section{Exchange}

The major function of the guanxi network is facilitating exchange. As Zhan argues, corrupt benefits are distributed according to "a preference ordering, with those closer to them enjoying higher priorities in receiving the corrupt benefits than those farther away". 82 Fieldwork data shows that guanxi and bribe payment are two determining factors for the buying and selling of military positions. ${ }^{83}$ To be specific, military positions come with price tags, but transactions between office sellers and buyers would not happen if assurances were not provided by guanxi networks. ${ }^{84}$

In the 1990s, office seekers tended to make payments after obtaining promotion and price tags for military positions did not exist. Trust, affection and moral obligation played essential roles in the buying and selling of military positions. Since the 2000s, bribe payments have become necessary for office buyers to reach agreement with office suppliers. That is to say, a buyer who wants to gain promotion has to meet the following conditions: (1) s/he has to accept the price tag and make payment beforehand; and (2) s/he must possess strong guanxi ties with the seller or find a middleperson whose request cannot be rejected by the seller. ${ }^{85}$ Interviewees point to two main reasons for the change in the timing of payment. Firstly, monetary success, as a principal cultural goal, has been instilled and enforced within the military since China's economic reform. As a former military officer argues:

From PLA officers' perspective, money becomes more and more important...power will expire when they retire, but money does not have an expiration date...in order to have a decent life after retirement, army officials have incentives to accumulate capital by transforming their power into money. ${ }^{86}$

Secondly, buyers tend to pay first because competition for promotion is getting tougher. In the 1980s and 1990s, lack of a university degree was the biggest obstacle

\footnotetext{
${ }^{79}$ Interview with Vivian Zhan, Hong Kong, 1 June 2015.

${ }^{80}$ Interview with former military officer L.

${ }^{81}$ Skype interview with former military officer O, June 2015.

${ }^{82}$ Zhan 2012, 102.

${ }^{83}$ Interview with former military officer G, Beijing, April 2015.

${ }^{84}$ Interview with military officer F; interview with military officer $\mathrm{H}$.

${ }^{85}$ Interview with former military officer L.

${ }^{86}$ Skype interview with former military officer O.
} 
for lower-level officers to gain promotion, but in the new millennium, the vast majority of PLA officers are university graduates. This means there are increasing numbers of qualified candidates for each position, giving rise to more competition for promotion. ${ }^{87}$ The use of corruption in career advancement has become a major way for PLA officers to seek psychological comfort. As a former military officer who is now a senior government official says:

Using payment to get things done (huaqian banshi, 花钱办事) is an old tradition and is still widely practiced today. Help seekers usually seek psychological comfort by paying bribes, because the acceptance of the payment by senior officers signals that what the seekers want is highly likely to be achieved. Refusing to accept payment means that there is no way to get things done. ${ }^{88}$

Bribe payment has become an important factor for ordinary military officers seeking promotion, which raises the question of whether highly competent candidates need to bribe senior officers. Fieldwork data shows that bribe payment is an indispensablealthough not, on its own, sufficient — aspect of obtaining career advancement even for competent officers. As an interviewee argues:

Competent officers face a dilemma: to pay or not to pay. They can either choose to pay a cheaper price (e.g. 50,000RMB) in advance to secure the promotion, or they have to pay a much higher price (e.g. 100,000RMB) for the same promotion if they fail in the competition of promotion due to the lack of payment beforehand...in reality, PLA officers are less likely to get promoted without payment. $^{89}$

Payment in advance is used by the buyer to signal trust and loyalty to the seller. Under such circumstances, the function of payment is to offer assurance for corrupt transactions. ${ }^{90}$ The buyer who chooses not to pay in advance usually fails to gain promotion and ends up having to pay more for the same position. The main reasons for paying a higher price include: (1) a PLA officer who misses the first promotion opportunity falls behind his or her peer group and thus feels much more pressure to gain promotion; and (2) the officer who is in charge of appointment and promotion has to find a new opportunity for the late payer, costing time and energy. ${ }^{91}$ In this case, the extra payment is to compensate the seller for the additional workload. Payments have become an indispensable element for PLA officers seeking promotion, but it is important to note that transactions will not happen if guanxi ties do not exist. The existence of guanxi networks - secret and safe trading platforms - is a necessary precondition for corrupt transactions.

\footnotetext{
${ }^{87}$ Interview with former military officer B, Tianjin, April 2015.

${ }^{88}$ Skype interview with former military officer $\mathrm{P}$.

${ }^{89}$ Interview with former military officer B.

${ }^{90}$ Interview, Vivian Zhan.

${ }^{91}$ Interview with former military officer B.
} 
The downfall of Xu Caihou, once the PLA's second-highest ranking officer, raises the question of why high-ranking officers engage in corruption. It is obvious that $\mathrm{Xu}$ had achieved culturally defined goals including high social status. Special benefits, including housing, health care and education, provided by the Chinese government to top government/military officers and their families make the accumulation of wealth unattractive. However, $\mathrm{Xu}$ was still deeply involved in selling military positions. News reports disclosed that one officer paid $\mathrm{Xu} 20$ million RMB to obtain a high rank. ${ }^{92}$ Interviewee perspectives help to make clear the importance of guanxi and cash payment in corrupt exchanges involving high-ranking officers:

$\mathrm{Xu}$ did not actually need the money, but the cash transactions were important for both $\mathrm{Xu}$ and the buyers. For office buyers, cash payment is the most important way for them to show their respect, appreciation and care...for office sellers, high-ranking officers find it impossible to meet the expectations of all the members of their extensive guanxi networks, thus a price tag for each position is helpful, allowing them to decline demands from guanxi members who are unable to pay...This lowers sellers' 'workloads' and avoids disputes with guanxi members. ${ }^{93}$

Cash payment, as interview data suggests, is perceived by military officers as the most efficient and effective way to create emotional bonding with superiors. ${ }^{94}$ Emotional components, such as love, care, appreciation and respect, are embedded in cash payments in corrupt transactions. The offer and acceptance of bribes is an important process for deepening ganqing and strengthening guanxi among corrupt officers. The stronger the emotional component, the closer the guanxi; the closer the guanxi, the more trust, assurance and security guanxi provides for corrupt exchanges.

Promotions and military positions have been transformed into commodities marketed through guanxi networks. A price tag for each position brings convenience to both the seller and the buyer, improving the efficiency of transactions. ${ }^{95}$ Price tags are helpful for transaction partners to avoid disputes and maintain face. With price tags, the seller avoids the embarrassment of asking the buyer directly for payment, and s/he can refuse requests from guanxi members who are not willing to pay. Equally, a price tag means the buyer does not need to guess how much s/he has to pay for the position. The absence of price tags brings uncertainty to the buying and selling of military positions. As an interviewee explains:

First, paying more than the seller's expected figure creates an extra financial burden for the buyer; second, paying less than the figure leads to dissatisfaction

\footnotetext{
${ }^{92}$ Caijing.com.cn. 2015. "Xu Caihou tamen jiakong dangshi de junwei lingdao ren” (Xu Caihou marginalized the former Chairman of the Central Military Commission), 9 March, http://politics.caijing.com.cn/20150309/3835125.shtml. Accessed 9 May 2015.

${ }^{93}$ Interview with former military officer J, Tianjin, April 2015.

${ }^{94}$ Skype interview with former military officer $\mathrm{P}$.

${ }^{95}$ Skype interview with former military officer $\mathrm{O}$.
} 
from other side, which can even result in transaction failure, loss of face and damaged guanxi. ${ }^{96}$

The study of military corruption in China reveals an enhanced level of commercialization in guanxi dealings, but it is important to note that corrupt exchanges are very different from ordinary market transactions. The illegal nature of corrupt exchanges prevents participants from resorting to legal protection and market mechanisms; participants therefore have to rely on alternative protection and enforcement mechanisms (e.g. guanxi). Moreover, the closeness of guanxi is an important factor for the allocation of military positions. Only military officers who have strong ties with their superiors and accept price tags are eligible to compete for important positions (e.g. the head of the cadre department and leaders of subordinate units). As an interviewee explains:

For senior officers, appointing candidates who are closer to them in the guanxi network to important positions is important due to three reasons: first, it ensures efficient cooperation among superiors and subordinates; second, it offers a safe environment for misconducts and corruption; third, it enables senior officers to retain their influence in the military after their retirement...for lower-level officers, they usually appreciate being given a chance of "buying" important positions because not all junior staff have such opportunities. The investment will be recovered quickly as new positions bring them more opportunities to abuse power to earn personal profit. ${ }^{97}$

\section{Neutralization}

According to $\mathrm{Li}$, guanxi norms (e.g. the principle of reciprocity and the norm of giftgiving) help break down the moral and cognitive barriers of corrupt transactions. ${ }^{98}$ "A government official is at the same time a private person embedded in a guanxi network"; s/he therefore feels obliged to meet demands from guanxi networks even though such demands usually conflict with social and legal norms. ${ }^{99}$ The study of buying promotions and selling positions in the PLA suggests that guanxi networks normalize corrupt transactions through the neutralization process.

The origin of neutralization theory can be found in Sykes and Matza's research on juvenile delinquency. ${ }^{100}$ Its main argument is that youth offenders tend to adopt techniques of neutralization to neutralize the guilt of delinquency behavior and rationalize their actions when they violate social norms. ${ }^{101}$ Neutralization theory is helpful to examine how corrupt PLA officers use guanxi norms to neutralize their guilt, lessen their responsibilities and protect their self-images. Fieldwork data

\footnotetext{
${ }^{96}$ Ibid.

${ }^{97}$ Skype interview with former military officer $\mathrm{P}$.

${ }^{98} \mathrm{Li}$, Ling 2011a.

${ }^{99}$ Zhan 2012, 104; see also Li, Ling 2011a.

${ }^{100}$ Sykes and Matza 1957.

${ }^{101}$ Copes 2015.
} 
suggests that corruption transactions are neutralized in two major ways: deny harm to the victim and appeal to guanxi norms.

Deny harm to the victim. Denial of harm is frequently used by transaction participants to rationalize their acts. In the military, the promotion of PLA officers is largely influenced by the practice of guanxi. ${ }^{102}$ Most officers believe they are justified in employing guanxi networks to gain promotion. According to their understanding, achieving career advancement through guanxi networks is fair and also widely accepted. ${ }^{103}$ As a former military officer says,

From the perspective of personal capacity, there is a lack of individual differences in the military. The absence of wartime challenges in the past three decades makes it difficult for senior officers to select competent officers...in most circumstances, almost all the candidates are qualified for promotion, but positions are very limited...in practice, competition for promotion is a game of guanxi competition. We all know that the strength and closeness of guanxi between candidates and superiors are determining factors... if you lose the game, you cannot blame anyone but yourself because you do not have enough guanxi resources. ${ }^{104}$

It is clear that corrupt guanxi networks harm the whole organization by distorting social norms and legal institutions. However, transaction participants look only at individual-level benefits rather than organizational costs. According to their understanding, it is hard to find a victim because all participants in such transactions are beneficiaries. As an interviewee argues:

If you are a middleman, you will find that facilitating transactions brings benefits to all parties involved: firstly, it helps the office sellers (senior officers) to earn profits; secondly, it enables the buyers to gain promotions; thirdly and most importantly, you create close ties with senior officers through assisting these transactions, thus senior officers are more likely to distribute promotions and opportunities to you in the future. You see, all are beneficiaries, no victims at all. $^{105}$

Appeal to guanxi norms. The PLA promotion system is characterized by a lack of transparency and checks and balances. This weak formal system fails to prevent senior officials from abusing power to meet the demands made on them by guanxi members. Buying promotions and selling military positions have therefore become highly embedded within guanxi networks. Participants in the buying and selling of military positions usually use the norms of guanxi to justify their behaviors.

\footnotetext{
${ }^{102}$ Interview with military officer F.

${ }^{103}$ Interview with military officer $\mathrm{H}$.

${ }^{104}$ Skype interview with former military officer O.

${ }^{105}$ Interview with former military officer L.
} 
Guanxi practitioners need to follow the rule of renqing, the main feature of which is 'the necessity of reciprocity, obligation and indebtedness in interpersonal relations'. ${ }^{106}$ To build closer guanxi, gift-giving within guanxi networks is widely practiced by Chinese people. ${ }^{107}$ Under intense competitive pressure and the popular culture of giftgiving, low- and mid-level military officers feel obliged to pay monetary compensation as a major way of showing their respect, care, gratitude and appreciation. It is an essential strategy for creating renqing and cultivating ganqing with senior officers. Accepting bribe payments containing emotional expressions is an obligation for senior officers, because declining to accept the payment will result in the breakdown in mutual affection (ganqing polie, 感情破裂), more disputes and even the destruction of senior officers' reputation within guanxi networks. The high cost of saying "no" to guanxi members, especially those who have strong ties, compels senior officers accept bribe payment. Acceptance generates further obligations and creates indebtedness: senior members must meet the expectations of bribers in order to return their renqing and deepen their ganqing. Guanxi norms such as reciprocity and obligation therefore create a vicious corrupt exchange circle of 'giving — accepting—returning'.

Guanxi members who fail to reciprocate favors are despised by other guanxi members as dishonest or lacking human feelings (mei renwei, 没人味). ${ }^{108}$ In an interview, a former military officer points out that:

Senior officers are "kidnapped" by guanxi networks. They feel obliged to assist those who are close to them within guanxi networks to obtain promotion...it is also an effective way for them to develop their reputation in guanxi networks and maintain influence in the military. ${ }^{109}$

In order to maintain and develop a favorable reputation, all payments will be returned to buyers if office sellers fail to deliver the promised corrupt benefits. ${ }^{110}$ Such informal mechanisms also prevent the buyers from reporting cases to the commissions of party discipline inspection, lowering the risk of detection and punishment. Another interviewee mentions the role of guanxi norms in combating office sellers' feelings of guilt:

Guanxi norms are fig leaves. They (corrupt officers) do not feel guilty or ashamed. They perceive that their involvement in illegal businesses is not just for themselves but also for their families, friends, brotherhoods, and wider groups (guanxi networks). High praise from guanxi members helps reduce guilty feelings (about committing corrupt acts). ${ }^{11}$

\footnotetext{
${ }^{106}$ Yang 1994: 122; see also Ke and Yue 2014.

${ }^{107}$ Xin and Pearce 1996.

${ }^{108}$ Interview with former military officer J.

${ }^{109}$ Interview with former military officer L.

${ }^{110}$ Interview with former military officer C.

${ }^{111}$ Skype interview with former military officer O.
} 
Similarly, recognition from guanxi members is important for the office buyer, because the seller is usually within the same guanxi network as the buyer. A bad reputation in guanxi networks leads to isolation, while a good reputation enhances the possibility of career advancement. ${ }^{112}$ In this case, guanxi norms are much more important to network members than social norms and legal institutions, and guanxi members' perceptions are more important than the perceptions of outsiders.

The discussion above indicates that guanxi facilitates the buying and selling of military positions through three ways: enhancing communications, guaranteeing exchanges and reducing moral hazards. These functions encourage military officers to make use of guanxi practices to advance personal interests and gain promotions.

\section{Conclusion}

This paper offers an exploratory study of the role of guanxi in facilitating the buying and selling of military positions. Fieldwork data suggests that the PLA's ineffective promotion system - the concentration of power and the lack of external monitoringencourages senior officers to allocate promotion opportunities by following guanxi rules rather than meritocratic principles. The buying and selling of military positions through guanxi practices is an attractive strategy for most PLA officers. Following in the footsteps of $\mathrm{Li}^{113}$ and Zhan, ${ }^{114}$ this paper contributes to the study of "the corruption-facilitating roles of guanxi" by examining how guanxi practices increase corrupt benefits and reduce the risk of punishment by offering a safe channel for communication, preventing nonperformance on either side and neutralizing the guilt of committing corruption. Using guanxi when buying and selling military positions is therefore a rational choice for officers seeking promotion.

This paper also investigates the relationship between bribe payment and guanxi in the buying and selling of military positions. In the new century, bribes have become an essential, although not sufficient, factor for corrupt exchanges. Bribes-usually in the form of cash payment - are a major way for buyers of promotion to express respect and appreciation and to create renqing and deepen ganqing with sellers of military position. Guanxi norms such as reciprocity and obligation help those involved in the transaction justify their actions and encourage military officers to satisfy guanxi members' needs regardless of laws and regulations. It is important to note that corrupt transactions would not happen if the assurance generated by guanxi practices did not exist. The degree of closeness of guanxi is also important when senior officers allocate promotion opportunities; only those who are closer to power holders in guanxi networks are qualified to compete for important positions.

Corruption is a global phenomenon, but the study of corruption in developing countries requires researchers to take local context and culture into consideration

\footnotetext{
${ }^{112}$ Ibid

${ }^{113} \mathrm{Li}$, Ling 2011a.

${ }^{114}$ Zhan 2012.
} 
rather than directly transplant of western theories. The integration of the concept of guanxi in the examination of military corruption in China allows the identification of the specific nature of corruption in the PLA. It offers a culturally-specific meaning and understanding of what causes PLA officers to engage in the selling and buying of positions and how military officers employ guanxi to tackle the environmental and behavioral uncertainties associated with corrupt exchanges. Incorporating the concept of guanxi also contributes to the understanding of the social and cultural embeddedness of corruption and provides valuable resources for comparative corruption research. 


\section{References}

Allen, Kenneth. 2010. "Assessing the PLA's promotion ladder to CMC member based on grades vs. ranks." China Brief 10(15): 6-9.

Allen, Kenneth. 2015. “The Top Trends in China's Military Diplomacy.” China Brief 15(9): $10-14$.

Allen, Kenneth W., and John F. Corbett. 2004. "Predicting PLA leader promotions." In Larry Wortzel and Andrew Scobell (eds.), Civil-Military Change in China Elites, Institutes, and Ideas after the 16th Party Congress. DIANE Publishing.

Allen, Kenneth., and Aaron Shraberg. 2011. "Assessing the Grade Structure for China's Aircraft Carriers: Part 2." China Brief 10(15): 7-11.

Balafoutas, Loukas. 2011. "Public beliefs and corruption in a repeated psychological game." Journal of Economic Behavior \& Organization 78(1): 51-59.

Bian, Yanjie. 1997. "Bringing strong ties back in: Indirect ties, network bridges, and job searches in China." American Sociological Review 62(3): 366-385.

Chan, Cheris Shun-ching. 2009. "Invigorating the Content in Social Embeddedness: An Ethnography of Life Insurance Transactions in China". American Journal of Sociology 115(3): 712-754.

Chang, Kuang-chi. 2011. "A Path to Understanding Guanxi in China's Transitional Economy: Variations on Network Behavior." Sociological Theory 29(4): 315-339.

Chao, Grace Lauren. 2013. "Elite Status in the People's Republic of China: Its formation and maintenance." PhD diss., Columbia University.

Chase, Michael S., Jeffrey Engstrom, Tai Ming Cheung, Kristen A. Gunness, Scott Warren Harold, Susan Puska, and Samuel K. Berkowitz. 2015. China's Incomplete Military Transformation Assessing the Weaknesses of the People's Liberation Army (PLA). RAND Corporation.

Chen, Chao C., Xiao-Ping Chen, and Shengsheng Huang. 2013. "Chinese Guanxi: An Integrative Review and New Directions for Future Research." Management and Organization Review 9(1): 167-207.

Cheung, Tai Ming. 2001. China's entrepreneurial army: The Structure, Activities, and Economic Returns of the Military Business Complex. Oxford: Oxford University Press.

Copes, Heith. 2015. "Neutralization Theory." Oxford Bibliographies in Criminology doi: 10.1093/obo/9780195396607-0140.

Della Porta, Donatella, and Alberto Vannucci. 2005. "The governance mechanisms of corrupt transactions." In J. G. Lambsdorff, M. Turcotte, and M. Schramm (eds.), The new institutional economics of corruption. London: Routledge 152-80.

Fan, Ying. 2002a. "Questioning guanxi: definition, classification and implications." International Business Review 11(5): 543-561. 
Fan, Ying. 2002b. "Guanxi's consequences: Personal gains at social cost." Journal of Business Ethics 38(4): 371-380.

Heimer, Maria, and Stig Thøgersen. 2006. Doing fieldwork in China. Denmark: NIAS Press.

Kaufman, Alison A., and Peter W. Mackenzie. 2009. The Culture of the Chinese People's Liberation Army. Arlington: CNA China Studies.

Ke, Zhujun, and Lei Yue. 2014. "A cultural examination of Chinese corruption from the angle of personal obligation.” Open Times 33(2): 210-223.

Keister, Lisa A. 2002. "Guanxi in business groups: Social ties and the formation of economic relations." In Thomas Gold, Doug Guthrie and David Wank (eds.), Social connections in China: Institutions, culture, and the changing nature of guanxi. Cambridge: Cambridge University Press 77-96.

King, Ambrose Yeo-chi. 1991. "Kuan-hsi and Network Building." Daedalus 120(2): 63-84.

Lambsdorff, Johann Graf. 2002. "Making corrupt deals: contracting in the shadow of the law." Journal of Economic Behavior \& Organization 48 (3): 221-41.

Li, Ling. 2011a. "Performing Bribery in China: Guanxi-Practice, Corruption with a Human Face." Journal of Contemporary China 20: 1-20.

Li, Ling. 2011b. "Lost in translation: the rule of guanxi, an alternative to the rule of law." In Michal Tomasek and Guido Muhlemann (eds.), Interpretation of law in China: Roots and perspectives. Karolinum Press 163-174.

Li, Xiaobing. 2012. China at War: An Encyclopedia. Santa Barbara: ABC-CLIO.

Lin, Tingjin. 2013. The politics of financing education in China. Palgrave Macmillan.

Lovett, Steve, Lee C. Simmons and Raja Kali. 1999. "Guanxi versus the market: Ethics and efficiency.” Journal of International Business Studies 30(2): 231-247.

Luo, Yadong. 2000. Guanxi and Business. New Jersey: World Scientific Publishing.

Luo, Yadong. 2008. "The Changing Chinese Culture and Business Behavior: The Perspective of Intertwinement between Guanxi and Corruption." International Business review 17: 18893.

McCauley, Kevin N. 2014. "Xi's Military Reform Plan: Accelerating Construction of a Strong PLA." China Brief 14(23): 11-15.

Merrilees, Bill. and Dale Miller 1999. "Direct selling in the west and east: The relative roles of product and relationship (guanxi) drivers." Journal of Business Research 45(3): 267-273.

Mulvenon, James. 2003. "To Get Rich Is Unprofessional: Chinese Military Corruption in the Jiang Era." China Leadership Monitor 6: 21-35.

Mulvenon, James. 2006. "So Crooked They Have to Screw Their Pants On: New Trends in Chinese Military Corruption.” China Leadership Monitor 19: 1-8. 
Mulvenon, James. 2015. "So Crooked They Have to Screw Their Pants On: Part 3: The Guo Boxiong Edition." China Leadership Monitor 48: 1-5.

Peng, Mike W. 2003. "Institutional Transitions and Strategic Choices." Academy of Management Review 28: 275-96.

Qi, Xiaoying. 2013. "Guanxi, social capital theory and beyond: toward a globalized social science." The British Journal of Sociology 64(2): 308-324.

Saunders, Phillip, and Andrew Scobell. 2015. PLA Influence on China's National Security Policymaking. Stanford, California: Stanford University Press.

Schramm, Matthias, and Markus Taube. 2004. "Private Ordering of Corrupt Transactions: The Case of the Chinese Guanxi Networks and Their Challenge by a Formal Legal System." In Johann Graf Lambsdorff, Markus Taube and Matthias Schramm (eds.), The New Institutional Economics of corruption. Routledge 181-97.

Scobell, Andrew, and Larry M. Wortzel. 2005. Chinese National Security Decision making under Stress. Carlisle/PA: Strategic Studies Institute, US Army War College.

Shieh, Shawn. 2005. "The Rise of Collective Corruption in China: the Xiamen smuggling case." Journal of Contemporary China 14(42): 67-91.

Sykes, Gresham, and David Matza. 1957. "Techniques of neutralization: A theory of delinquency." American Sociological Review 22: 664-670.

Tsang, Eric W. K. 1998. "Can guanxi be a source of sustained competitive advantage for doing business in China?" The Academy of Management Executive 12(2): 64-73.

Wang, Chunyu, Jingzhong Ye, and Jennifer C. Franco. 2014. "Local State Corporatism or Neo-Guanxilism? Observations From the County Level of Government in China." Journal of Contemporary China 23: 498-515.

Wang, Cheng Lu. 2007. "Guanxi vs. Relationship Marketing: Exploring Underlying Differences.” Industrial Marketing Management 36: 81-86.

Wang, Peng. 2013. "The rise of the Red Mafia in China: a case study of organised crime and corruption in Chongqing." Trends in Organized crime 16(1): $49-73$.

Wang, Peng. 2014. "Extra-Legal Protection in China How Guanxi Distorts China's Legal System and Facilitates the Rise of Unlawful Protectors." British Journal of Criminology 54(5): 809-830.

Wang, Peng. 2015. "Organized crime and illegal gambling: How do illegal gambling enterprises respond to the challenges posed by their illegality in China?" Australian \& New Zealand Journal of Criminology doi: 10.1177/0004865815573874.

Wu, Wei-ping, and Alicia Leung. 2005. "Does a micro-macro link exist between managerial value of reciprocity, social capital and firm performance? The case of SMEs in China." Asia Pacific Journal of Management 22(4): 445-463. 
Xin, Katherine Ki, and John L. Pearce. 1996. "Guanxi: Connections as substitutes for formal institutional support.” Academy of Management Journal 39(6): 1641-1658.

Yang, Mayfair Mei-hui. 1994. Gifts, favors, and banquets: The art of social relationships in China. Cornell University Press.

Yu, Keping. 2010. Democracy and the Rule of Law in China. Leiden: Brill.

Zeng, Qingjie. 2015. "Democratic Procedures in the CCP's Cadre Selection Process: Implementation and Consequences." The China Quarterly, 225: 1-27.

Zhan, Jing Vivian. 2012. "Filling the Gap of Formal Institutions: The Effects of Guanxi Network on Corruption in Reform-Era China." Crime, Law and Social Change 58: 93-109.

Zuo, Cai Vera. 2015. "Promoting City Leaders: The Structure of Political Incentives in China." The China Quarterly, 224: 955-984. 